\title{
Decreased Motor Neuron Support by SMA Astrocytes due to Diminished MCP1 Secretion
}

\author{
Jasmin E. Martin, ${ }^{1 \star}$ 다rangKimberly T. Nguyen, ${ }^{1 \star}$ Christopher Grunseich, ${ }^{1}$ Jonathan H. Nofziger, ${ }^{1}$ Philip R. Lee, ${ }^{2}$ \\ Douglas Fields, ${ }^{2}$ Kenneth H. Fischbeck, ${ }^{1}$ and Emily Foran ${ }^{1}$ \\ ${ }^{1}$ Neurogenetics Branch, National Institute of Neurological Disorders and Stroke, and ${ }^{2}$ Section on Nervous System Development and Plasticity, Eunice \\ Kennedy Shriver National Institutes of Child Health and Human Development, National Institutes of Health, Bethesda, Maryland 20892
}

\begin{abstract}
Spinal muscular atrophy (SMA) is an autosomal-recessive disorder characterized by severe, often fatal muscle weakness due to loss of motor neurons. SMA patients have deletions and other mutations of the survival of motor neuron 1 (SMN1) gene, resulting in decreased SMN protein. Astrocytes are the primary support cells of the CNS and are responsible for glutamate clearance, metabolic support, response to injury, and regulation of signal transmission. Astrocytes have been implicated in SMA as in in other neurodegenerative disorders. Astrocyte-specific rescue of SMN protein levels has been shown to mitigate disease manifestations in mice. However, the mechanism by which SMN deficiency in astrocytes may contribute to SMA is unclear and what aspect of astrocyte activity is lacking is unknown. Therefore, it is worthwhile to identify defects in SMN-deficient astrocytes that compromise normal function. We show here that SMA astrocyte cultures derived from mouse spinal cord of both sexes are deficient in supporting both WT and SMN-deficient motor neurons derived from male, female, and mixed-sex sources and that this deficiency may be mitigated with secreted factors. In particular, SMN-deficient astrocytes have decreased levels of monocyte chemoactive protein 1 (MCP1) secretion compared with controls and MCP1 restoration stimulates outgrowth of neurites from cultured motor neurons. Correction of MCP1 deficiency may thus be a new therapeutic approach to SMA.
\end{abstract}

Key words: astrocytes; iPSC; MCP1/CCL2; motor neuron; spinal muscular atrophy

\section{Significance Statement}

Spinal muscular atrophy (SMA) is caused by the loss of motor neurons, but astrocyte dysfunction also contributes to the disease in mouse models. Monocyte chemoactive protein 1 (MCP1) has been shown to be neuroprotective and is released by astrocytes. Here, we report that MCP1 levels are decreased in SMA mice and that replacement of deficient MCP1 increases differentiation and neurite length of WT and SMN-deficient motor-neuron-like cells in cell culture. This study reveals a novel aspect of astrocyte dysfunction in SMA and indicates a possible approach for improving motor neuron growth and survival in this disease.

\section{Introduction}

Spinal muscular atrophy (SMA) is the most common inherited cause of death in infants and young children. The incidence is estimated to be 1 in $10-12,000$ live births and the carrier rate is

\footnotetext{
Received Nov. 9, 2016; revised April 7, 2017; accepted April 19, 2017

Author contributions: C.G., P.R.L., and E.F. designed research; J.E.M., T.T.N., C.G., J.H.N., and E.F. performed research; C.G., P.R.L., and D.F. contributed unpublished reagents/analytic tools;J.E.M., T.T.N., P.R.L., D.F., K.H.F., and E.F. analyzed data; J.E.M., T.T.N., K.H.F., and E.F. wrote the paper.

This work was primarily supported by National Institute of Neurological Disorders and Stroke intramural research funds. P.R.L. and D.F. were supported by intramural research funds from the Eunice Kennedy Shriver National Institute of Child Health and Human Development (NICHD). We thank William Huffman (NICHD) for help with embryonic spinal cord dissections.

The authors declare no competing financial interests.

*J.E.M. and T.T.N. contributed equally to this work.

Correspondence should be addressed to Emily Foran, Neurogenetics Branch, National Institute of Neurological Disorders and Stroke, 6001 Executive Drive, 2121A, Rockville, MD 20852. E-mail: Emily.Carifi@nih.gov.

DOI:10.1523/JNEUROSCI.3472-16.2017

Copyright $\odot 2017$ the authors $\quad 0270-6474 / 17 / 375309-10 \$ 15.00 / 0$
}

$\sim 1$ in 50 in populations of European and Asian descent (Pearn, 1973; Sugarman et al., 2012).

SMA results from deletions and other mutations in the survival motor neuron 1 (SMN1) gene, leading to loss of SMN protein (Coovert et al., 1997; Lefebvre et al., 1997). Humans have an SMN1 homolog, SMN2, which primarily encodes a truncated and rapidly degraded protein product due to a nucleotide substitution that leads to the exclusion of exon 7 (Monani et al., 1999).

In SMA, there are intrinsic deficits in motor neurons (Monani, 2005; Burghes and Beattie 2009; Park et al., 2010; Gogliotti et al., 2012) and the clinical manifestations are linked to the dysfunction of motor neurons and the neuromuscular junction. Ubiquitous reversal of SMN deficiency early in life is sufficient to rescue a mouse model and to give the mice normal motor function and lifespan (Foust et al., 2010; Robbins et al., 2014). However, experiments in mouse models have shown that restoring SMN protein levels in motor neurons alone, while resulting in 
A
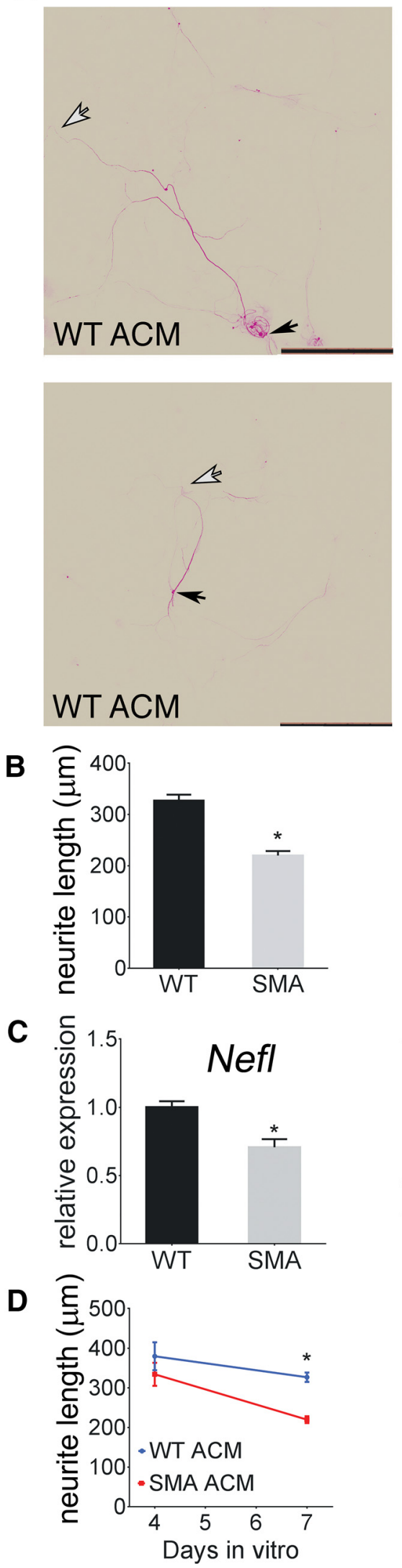
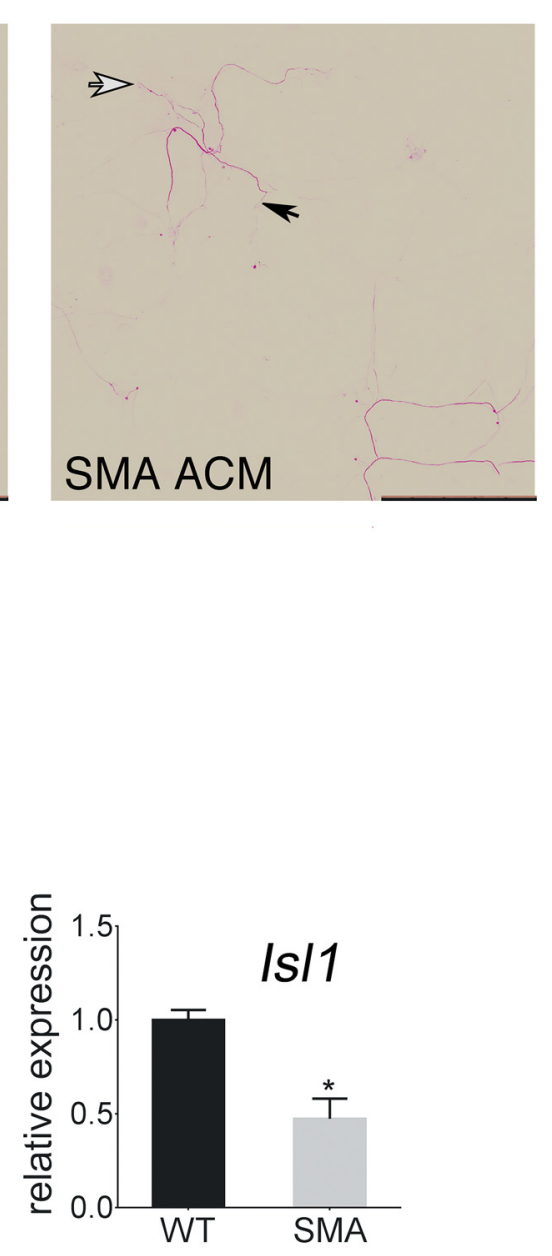

SMA ACM

SMA ACM
Figure 1. Cultured WT mouse spinal cord motor neurons have shorter neurites and express lower levels of motor neuron markers when grown in the presence of SMA ACM compared with WT ACM. Motor neurons were derived from WT mouse E13.5 spinal cords. The neurons were treated $24 \mathrm{~h}$ after plating for $7 \mathrm{~d}$ with ACM from astrocytes from the spinal cords of either SMA or WT littermate pups. $\boldsymbol{A}$, Primary neurites identified by SMI-32 immunostaining. Scale bar, $250 \mu \mathrm{m}$. The cell soma is indicated by a black improvement in motor function and reducing weight loss, does not extend lifespan significantly (Lee et al., 2012; Martinez et al., 2012). It has been shown that supporting astroglial cells contribute to the SMA phenotype and selective rescue of SMN deficiency in astrocytes slows disease progression in a mouse model of SMA (Rindt et al., 2015). In addition, SMN-deficient astrocytes have calcium wave deficits, reduced release of glial-derived neurotrophic factor (GDNF), increased activation unrelated to oxidative stress (McGivern et al., 2013; Patitucci and Ebert, 2016), and less support of motor neuron synapse formation in culture (Zhou et al., 2016). In other neurodegenerative disorders, astrocytes have alterations that can contribute to the disease manifestation and progression (Clement et al., 2003; Miao et al., 2014; Tong et al., 2014; Jiang et al., 2016). Incorporation of healthy astrocytes ameliorates disease manifestations in amyotrophic lateral sclerosis (ALS) mouse models (Clement et al., 2003, Kondo et al., 2014). Defective astrocytes can contribute to neuronal dysfunction in several ways, including deficient neuronal support (Jeong et al., 2014), secretion of a toxic factor (Pehar et al., 2004), and contactdependent toxicity.

However, just how SMN deficiency in astrocytes results in motor neuron loss has not been fully elucidated and further examination of how these cells interact may provide therapeutic targets. Astrocytes secrete supportive and directional factors that can promote motor neuron health and survival. One such factor, monocyte chemoactive protein 1 (MCP1, also known as CCL2), has been linked to neuronal protection from excitotoxicity (Madrigal et al., 2009), the survival of acoustic ganglion neurons during development (Bianchi et al., 2005), and regeneration and neurite outgrowth after preconditioning stress (Stowe et al., 2012).

We tested the hypothesis that healthy astrocytes are required to maintain healthy motor neuron function and that SMN-

\footnotetext{
$\leftarrow$

arrow and the end of a measured neurite by a white arrow. $B$, A minimum of 20 neurons were measured and quantified by a blinded evaluator $(p=0.001)$. C, Relative mRNA levels of Nefl $(p=0.02)$ and IsI1 $(p=0.002)$ are reduced in neurons grown in the presence of SMA ACM. D, At $4 d$, the neurite lengths are similar between WT and SMA, but at $7 d$, the motor neuron neurites in SMA ACM were significantly shorter than the motor neuron neurites grown in WTACM $(p=0.02)$. Neurite data are shown as mean \pm SEM. Relative mRNA levels are normalized to Pgk1 and mRNA data shown are presented as mean \pm SD
} 

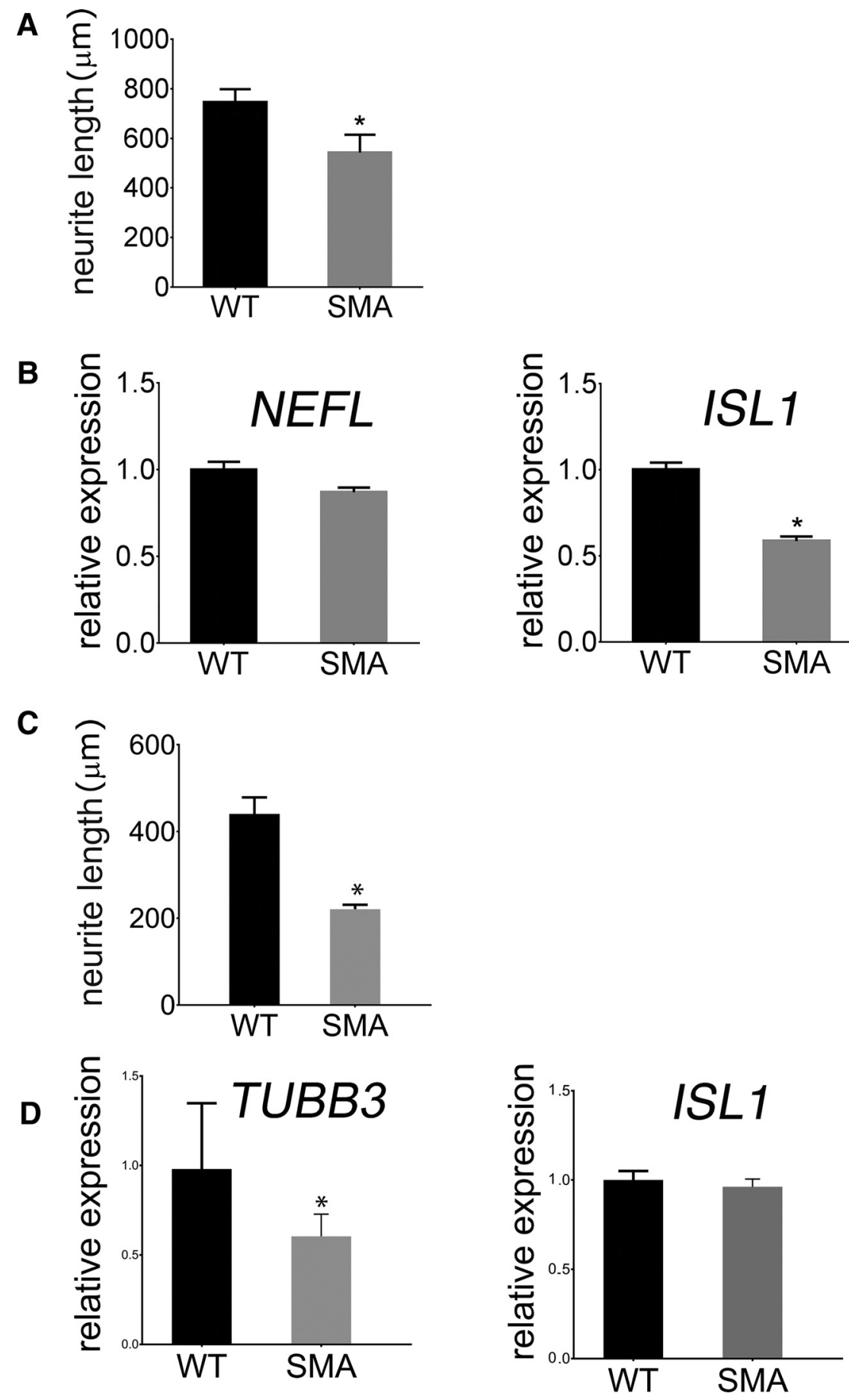

Figure 2. Differentiated motor-neuron-like cells from healthy control iPSCs have shorter neurites and express lower levels of motor neuron markers when grown in the presence of SMA ACM compared with WT ACM. IPSCs were differentiated into motorneuron-like cells. The neurons were treated $24 \mathrm{~h}$ after plating for $7 \mathrm{~d}$ with $\mathrm{ACM}$ from astrocytes from the spinal cords of either SMA or WT littermate pups. $\boldsymbol{A}, A$ minimum of 20 neurons were measured and quantified $(p=0.009)$. $\boldsymbol{B}$, Relative mRNA levels of $|\mathrm{s}| 1$ $(p=0.001)$ are reduced in neurons grown in the presence of SMA ACM. Differentiated motor neurons from SMA patient iPSCs have shorter neurites and express lower levels of motor neuron markers when grown in the presence of SMA ACM compared with WT ACM. C, A minimum of 20 neurons were measured and quantified $(p=0.03)$. D, Relative mRNA levels of TUBB3 $(p=0.02)$ are reduced in neurons grown in the presence of SMA ACM. Neurite data are shown as mean \pm SEM. Relative mRNA levels are normalized to Pgk1 and GusB and mRNA data shown are presented as mean \pm SD.

deficient astrocytes are less able to do so. We found that conditioned medium from SMN-deficient astrocytes has decreased support of both WT and SMN-deficient motor neuron growth in culture. We also found that the amount of MCP1 released by SMA astrocytes is reduced compared with WT astrocytes. The ad- dition of MCP1 to motor neuron cultures increases neurite length and expression of motor neuron markers and neutralization of MCP1 prevents the positive effects of WT astrocyte-conditioned medium (ACM) on motor neurons.

Considering the evidence that early restoration of SMN to astrocytes improves the mouse phenotype and that MCP1 has been linked to developmental survival and regeneration of neuronal cell types, our observations indicate that MCP1 restoration may be worth pursuing as a new approach to treatment for SMA.

\section{Materials and Methods}

Transgenic mice. All experiments were performed in accordance with the National Institutes of Health's Guide for the Care and Use of Laboratory Animals and were approved by the National Institute for Neurological Disorders and Stroke (NINDS) Animal Care and Use Committee. $\mathrm{Smn}{ }^{+/-} / \mathrm{SMN} 2^{+/+} / \mathrm{SMN} \Delta 7^{+/+}$ (SMA $\Delta 7)$ mice on the FVB background were obtained from The Jackson Laboratory and bred in our facility. The breeding colony was maintained by interbreeding heterozygous mice and offspring were genotyped using PCR on tail DNA. The primers used were GTG TCT GGG CTG TAG GCA TTG C and GGC TGT GCC TTT TGG CTT ATC TG for the SMN2 transgene and GCC TGC GAT GTC GGT TTC TGT GAG G and CCA GCG CGG ATC GGT CAG ACG for the $\beta$ gal transgene (Integrated DNA Technologies).

Primary astrocyte cultures. Astrocytes were prepared from newborn mice of both sexes (adapted from Gibb et al., 2007). In brief, four to six spinal cords dissected from postnatal day 2 (P2)-P3 mice were pooled for each condition (WT and SMA). The tissue was digested with trypsin/DNase solution (Worthington) followed by mechanical dissociation. The cells were resuspended in $4 \mathrm{ml}$ of astrocyte medium (Dulbecco's Modified Eagle Media F12 Ham, 1:1; Invitrogen), $20 \%$ fetal bovine serum, Primocin (1:1000), and Fungin (1:500) (InvivoGen), and plated in T75 flasks. When confluent, the cells were shaken overnight at 220 RPM for three nights with the medium changed each day. After shaking, the astrocytes were collected, the medium was aspirated, and the cells were washed twice with Hank's balanced salt solution (Invitrogen). Then, $0.1 \%$ trypsin in PBS was added to each flask so that it covered the cells and the mixture incubated at $37^{\circ} \mathrm{C}$ for $1 \mathrm{~min}$ or until the cells began to lift. Mechanical disruption was used to remove all cells from the flask. Once cells had lifted completely, astrocyte medium was added. The cells were centrifuged and resuspended in $4 \mathrm{ml}$ of warm astrocyte medium. Cell counts were done with a Cell-o-meter (Bio-Rad) and the indicated number of cells was plated for each experiment.

ACM. Confluent six-well plates of astrocytes were grown in Neurobasal complete medium (containing Neurobasal medium, N2 supplement, and penicillin-streptomycin; Invitrogen) for $7 \mathrm{~d}$. Every $48 \mathrm{~h}$, half 


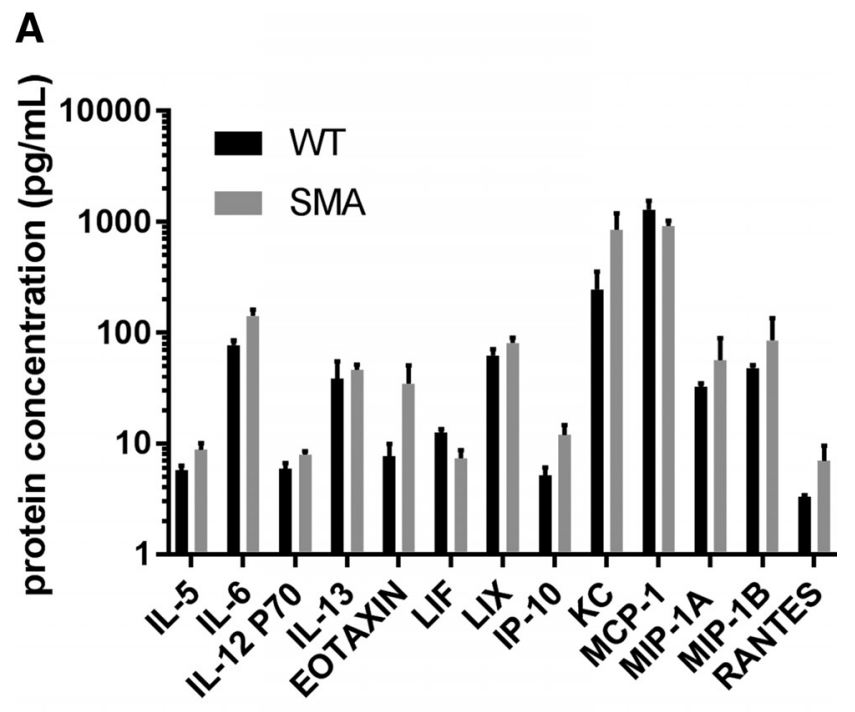

B

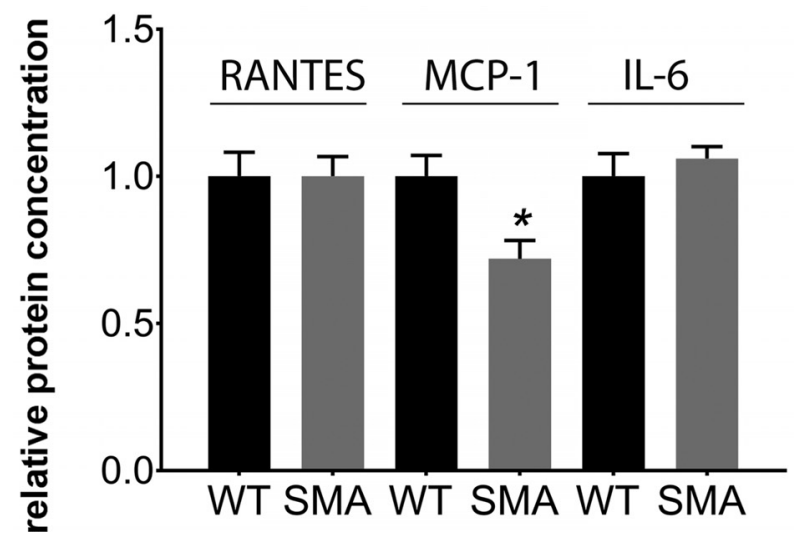

Figure 3. MCP1 levels are decreased in SMA ACM compared with WT ACM. Astrocytes were cultured from P2 neonatal mouse spinal cord by enzymatic and mechanical disruption. Once confluent, the cells were incubated with complete astrocyte medium for $5 \mathrm{~d}$. The medium was then collected and tested using a 32 chemokine panel from the University of Maryland Cytokine Core Laboratory. $A$, Cytokines within detectable limits and with a $20 \%$ difference between the WT and SMA average values are shown (protein values in $\mathrm{pg} / \mathrm{ml}$ ). $\boldsymbol{B}$, secondary validation using a sandwich ELISA for MCP1, RANTES, and IL-6 (blinded). All ELISA data are shown as mean \pm SD $(p=0.01)$.

of the medium was removed and centrifuged at $1000 \times g$ to remove cells and debris. The supernatant was added 50:50 to fresh Neurobasal complete medium and the medium was added to plated neurons.

Primary motor neuron cultures. Motor neurons were obtained from mouse embryos of both sexes at embryonic day 13.5 (E13.5) using a method adapted from Taylor et al. (2007). Briefly, 4-6 spinal cords were dissected and incubated in $0.025 \%$ trypsin for $8 \mathrm{~min}$, followed by mechanical dissociation, and wee then enriched by centrifugation through serial bovine serum albumin and Optiprep (Iodiaxonal; Sigma-Aldrich) gradients. The cells were plated on eight-chamber slides coated with poly-L-ornithine (Sigma-Aldrich) and laminin (Roche) in Neurobasal complete medium.

Human induced pluripotent stem cell (iPSC) differentiation to motorneuron-like cells. Control and SMA patient iPSCs of both sexes, derived in our laboratory, were differentiated to motor-neuron-like cells (Grunseich et al., 2014). In brief, the cells were grown to confluency, lifted with collagenase, and transferred to a nonadherent plate to form embryoid bodies. The embryoid bodies were expanded with medium and supplement changes to neuralize, caudalize, and then ventralize the cells to become like ventral horn motor neurons. After $15 \mathrm{~d}$, the cells were plated in coated eight-well dishes and incubated in medium containing growth

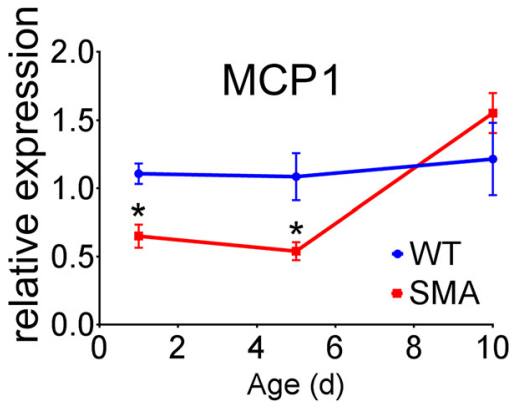

Figure 4. MCP1 mRNA levels are decreased in young SMA mouse spinal cords compared with unaffected littermate controls. MCP1 mRNA levels from spinal cords from P1, P5, and P10 mice were quantified using $\mathrm{QPCR}$ by a blinded evaluator. Relative mRNA levels are normalized to Pgk1. Data are shown as mean \pm SEM (day $0, p=0.0004$; day $5, p=0.02$ ).

factors overnight. Twenty-four hours after plating, the cells were treated with ACM with or without neutralizing antibody to MCP1 (Millipore, 1:500) or IL-6 (R\&D Systems) or with or without MCP1 or IL-6 supplementation for $7 \mathrm{~d}$. The media and MCP1 or IL- 6 were refreshed every other day.

Tissue collection. Six mice of either sex per time point per genotype were anesthetized with isofluorene gas and decapitated. The spinal cords were removed using sterile PBS in a $13 \mathrm{ml}$ syringe with an $18-1 / 2$ Ga needle and immediately placed in liquid nitrogen or processed for analysis.

Antibodies. Primary antibodies were SMI-32 (Abcam, 1:2500) and Islet1 (DSHB,1:200). Secondary antibodies were Alexa Fluor (Invitrogen, 1:500), goat anti-mouse 488, and goat anti-chicken 647.

RNA extraction and DNA conversion. RNA was collected with TRIzol reagent (Life Technologies) according to the manufacturer's protocol. Phase separation with chloroform was performed; the aqueous, RNAcontaining layer was collected and RNA was precipitated with isopropanol. The precipitated RNA was then resuspended in water. High-capacity reverse transcriptase (Roche) was used to convert $1 \mu \mathrm{g}$ of RNA per sample to cDNA using a thermocycler (Bio-Rad).

RNA probes and real-time qPCR primers and probes used to amplify RNA were from Invitrogen. The following primers and probes were used to amplify the respective cDNA product: SMN, MCPI/CCL2, Isl1, TUBB3, Nefl, PGK1, and GUSB. All analysis was performed on QuantStudio 6 Flex (Invitrogen).

ELISA. The University of Maryland Cytokine Laboratory performed an array analysis of 32 mouse chemokines, including GCSF, eotaxin, GMCSF, IFN-G, IL-1A, IL-1B, IL-2, IL-4, IL-3, IL-5, IL-6, IL-7, IL-9, IL-10, IL-12 P40, IL-12 P70, LIF, IL-13, LIX, IL-15, IL-17, IP-10, KC, MCP-1, MIP-1A, MIP-1B, MCSF, MIP-2, MIG, RANTES, VEGF, and TNF-A. The mouse chemokines that were within detectable levels and showed a 20\% difference between SMA and WT are represented in the figures. Sandwich ELISA kits (Abcam) were used to determine the concentrations of the secreted proteins. Samples used were cell culture media from astrocytes after a $7 \mathrm{~d}$ incubation; each ELISA was replicated at least 3 times with independent astrocyte preparations. ELISAs were performed according to the protocols that accompanied each kit (MCPI, RANTES, IL-6). Data are expressed as relative protein expression compared with WT astrocytes.

Immunofluorescence of cultured cells. Plated motor neurons were prepared for confocal imaging as described for astrocytes in Foran et al. (2014). In brief, plated cells were washed with PBS, fixed with $4 \%$ paraformaldehyde (Electron Microscopy Systems), dehydrated in 100\% methanol, blocked with 5\% normal goat serum (Jackson Laboratory), permeabilized with $0.5 \%$ Triton X-100 (Sigma-Aldrich), and then treated with primary antibody (Islet1 and SMI-32) overnight and secondary antibody (Alexa Fluor; Invitrogen) for $1 \mathrm{~h}$ in the dark. Coverslips were applied with Prolong Diamond Antifade and DAPI (Invitrogen).

Cell counts and assessment of neurite length. Motor neurons were plated at a density of $10^{5}$ cells per milliliter and cultured for 1 week. ACM was added at a ratio of 50:50 to normal motor neuron media every other day. 

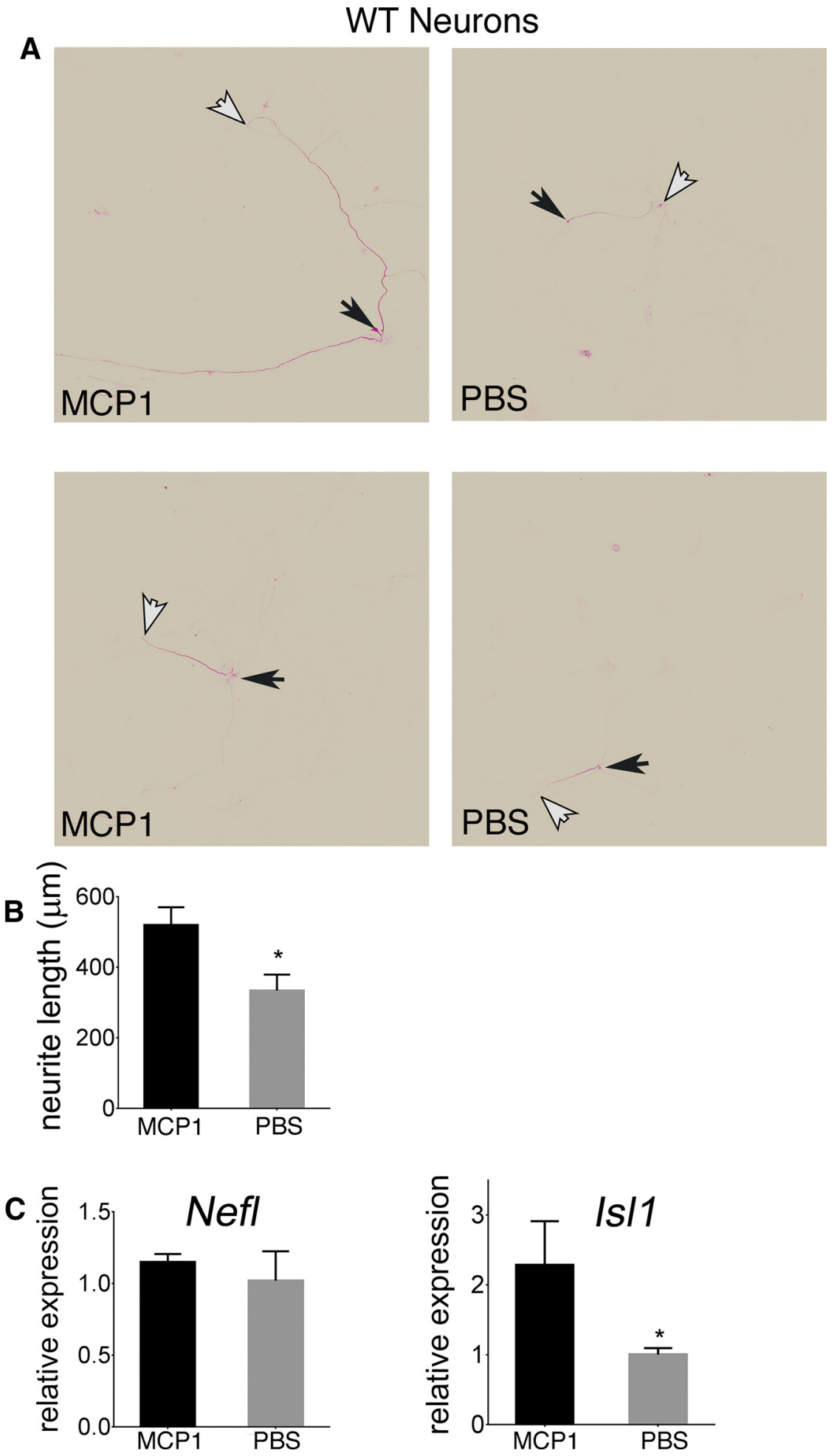

Figure 5. Application of exogenous MCP1 increases the neurite length of cultured WT mouse spinal cord motor neurons. Motor neurons were derived from WT mouse E13.5 spinal cords. The neurons were treated $24 \mathrm{~h}$ after plating for $7 \mathrm{~d}$ with $500 \mathrm{pg} / \mathrm{ml} \mathrm{of}$ media recombinant MCP1 or PBS. A, Primary neurites as indicated by SMI-32 immunostaining. $\boldsymbol{A}, \boldsymbol{B}, \mathrm{A}$ minimum of 20 neurons were measured and quantified ( $p=0.04$ ). Cell soma are indicated by a black arrow and the end of a measured neurite by a white arrow. $C$, Relative mRNA levels of $|s| 1(p=0.05)$ are increased in isolated neurons grown in the presence of recombinant MCP1. Neurite data are shown as mean \pm SEM. Relative mRNA levels are normalized to Pgk1. mRNA data are shown as mean \pm SD.

The cells were fixed and stained for Islet1, a motor neuron marker, and SMI32, a neurofilament highly expressed by motor neurons. A minimum of five randomly selected fields per well were imaged to ensure that a sufficient number of neurons was captured. Neurite length was assessed by measuring the SMI32-positive neurites of Islet1-positive cells and measurements were made with the NeuronJ plugin for ImageJ. A minimum of 20 neurons per condition per experiment were measured and each experiment was replicated four times. The average neurite lengths of neurons grown with SMN-deficient or control astrocytes were compared.

Experimental design and statistical analyses. Analyses of neurite length, ELISAs, and mRNA quantification were done by observers blinded to ACM condition and the presence or absence of recombinant MCP1 or IL-6 or neutralizing MCP1 or IL- 6 antibody. For all neurite comparisons, $n=20$ or greater; for all ELISA and mRNA comparisons, $n=3$ or greater. Two tailed Student's $t$ tests were used to analyze all comparison data.

\section{Results}

SMA $\Delta 7$ mouse ACM provides decreased support of isolated motor neurons

Isolated mouse spinal cord motor neurons grow in culture when supplemented with growth factors. Media conditioned with astrocytes will also support the prolonged growth of isolated motor neurons. This support is provided by a combination of secreted factors from the astrocytes. We set out to determine whether there is a difference in support capacity between SMA $\Delta 7\left(\mathrm{Smn}^{-/-} / \mathrm{SMN} 2^{+/+}\right.$, $\operatorname{SMN} \Delta 7^{+/+}$mice on an FVB background) mouse astrocytes and astrocytes from the WT littermate controls. Isolated spinal cord motor neurons grown in SMA ACM had shorter axons (Fig. $1 A, B$ ) and less mRNA expression of the motor neuron markers Nefl and Isl1 compared with motor neurons grown in ACM from WT littermates (Fig. 1C). We used the expression of these motor-neuron-specific genes relative to the housekeeping genes $P G K 1$ and $G u s B$ as a surrogate for motor neuron health and survival. The decrease in motor-neuron-specific gene expression indicates less persistence of motor neurons.

The relative neurite length decreased over time. At $4 \mathrm{~d}$ in culture, the lengths of neurites grown in SMA or WT ACM was similar, but at $7 \mathrm{~d}$, the length of SMA ACMexposed neurites had decreased more than the WT ACM-exposed neurites (Fig. 1D).

We sought to determine whether human neurons are also vulnerable to the diminished support of SMA astrocytes. Human iPSCs can be directed to motor neuron lineages with appropriate media and morphogen exposure. After differentiation iPS-cell-derived motor-neuron-like cells grown in SMA ACM had shorter neurites compared with iPS-cell-derived neurons grown in WT ACM (Fig. 2A). The mRNA levels for Isl1 were also decreased 
in the iPS-cell-derived motor-neuron-like cells grown in SMA ACM (Fig. 2B).

We also sought to determine whether SMA motor neuron neurite growth was also affected differentially by SMA or WT ACM. After differentiation SMA patient iPS-cell-derived motor neurons grown in SMA ACM had shorter neurites compared with iPS-cell-derived neurons grown in WT ACM (Fig. 2C). The mRNA levels for TUBB3 were also decreased in the iPS-cellderived motor neurons grown in SMA ACM (Fig. 2D).

\section{SMA astrocytes produce decreased amounts of MCP1}

We investigated which factors were increased or decreased in SMA ACM in a manner that may have led to the altered motor neuron neurite outgrowth. There were several alterations to the chemokine/ cytokine secretion profile of the SMA astrocytes compared with WT control astrocytes. The chemokines with a $20 \%$ difference between the SMA and WT groups are shown (Fig. 3A). Previously published studies reported that RANTES, IL6, and MCP1 increased the survival of neurons (Bruno et al., 2000; Pavelko et al., 2003; Rosito et al., 2012). We verified by ELISA that MCP1 levels are significantly decreased (Fig. $3 B$ ), but we saw no difference with RANTES or IL-6.

After collecting the data from isolated astrocyte cultures, we sought to verify that the MCP1 alterations also occur in vivo in SMA mice. We found that MCP1 mRNA levels are lower in the spinal cords of P1 and P5 SMA mice compared with WT littermate controls (Fig. 4).

\section{MCP1 supplementation improves motor neuron growth}

We also sought to verify that MCP1 increases neurite length in cultured neurons. The addition of $500 \mathrm{pg}$ of recombinant MCP1 increased neurite outgrowth in isolated primary mouse motor neurons (Fig. $5 A, B)$. The mRNA levels for the motor neuron marker Isl1 were also increased with exogenous MCP1 (Fig. 5C). Motor neurons express CCR2, the receptor for MCP1 (Coughlan et al., 2000 and data not shown). Similar effects were not seen with the addition of recombinant IL-6 (data not shown).

Motor neurons differentiated from control human iPSCs were also sensitive to MCP1 treatment. The neurons grown in the presence of $500 \mathrm{pg}$ of MCP1 had longer neurites (Fig. 6A) and higher mRNA levels of Nefl mRNA (Fig. 6B). In addition, recombinant MCP1 increased neurite length of motor neurons derived from SMA patient iPSCs (Fig. 6C), but did not significantly elevate motor neuron mRNA levels (Fig. $6 D$ ).
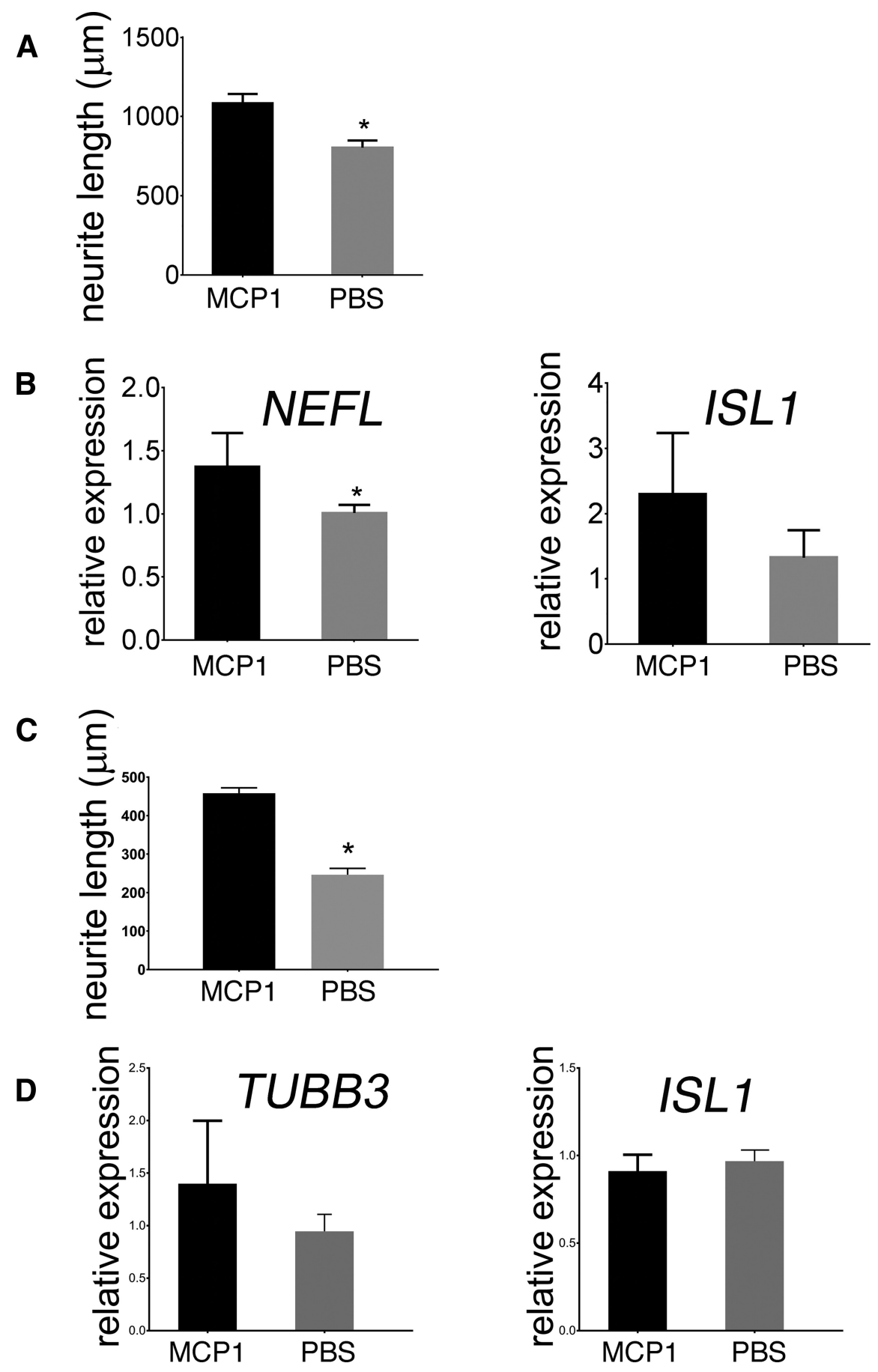

Figure 6. Application of exogenous MCP1 increases the neurite length of motor-neuron-like cells derived from human control and SMA iPSCS. The cells were treated $24 \mathrm{~h}$ after plating for $7 \mathrm{~d}$ with $500 \mathrm{pg} / \mathrm{ml}$ exogenous MCP1 or PBS. $A, A$ minimum of 20 neurons were measured and quantified $(p=0.02)$. $\boldsymbol{B}$, Relative mRNA levels of Nefl $(p=0.05)$ are increased in neurons grown in the presence of recombinant MCP1. Application of exogenous MCP1 increases the neurite length of motor-neuron-like cells derived from SMA patient iPSCS. The cells were treated $24 \mathrm{~h}$ after plating for $7 \mathrm{~d}$ with $500 \mathrm{pg} / \mathrm{ml}$ exogenous MCP1 or PBS. C, A minimum of 20 neurons were measured and quantified $(p=0.002$ ). $D$, Relative mRNA levels of TUBB3 and Isl 1 are unchanged in SMA neurons grown in the presence of recombinant MCP1. Neurite data are shown as mean \pm SEM. Relative mRNA levels are normalized to Pgk1 and GusB. mRNA data are shown as mean \pm SD.

We found that the action of MCP1 was directly on the motor neurons and was not mediated through autocrine signaling within the astrocytes. Astrocytes were treated with recombinant MCP1 for $24 \mathrm{~h}$ and ACM from the treated cells was added to motor neurons as above. No alteration to motor neuron phenotype was seen (data not shown). 


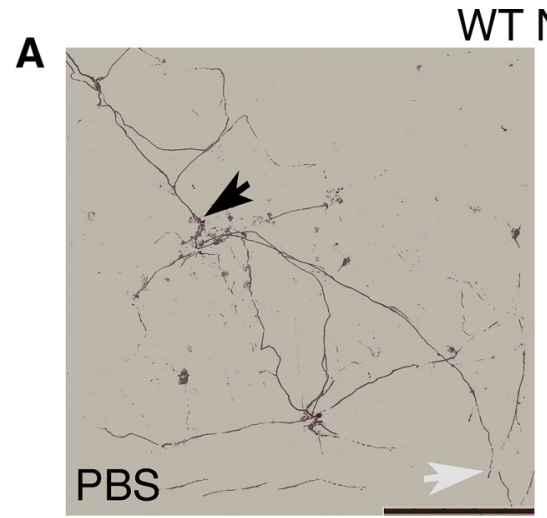

WT Neurons
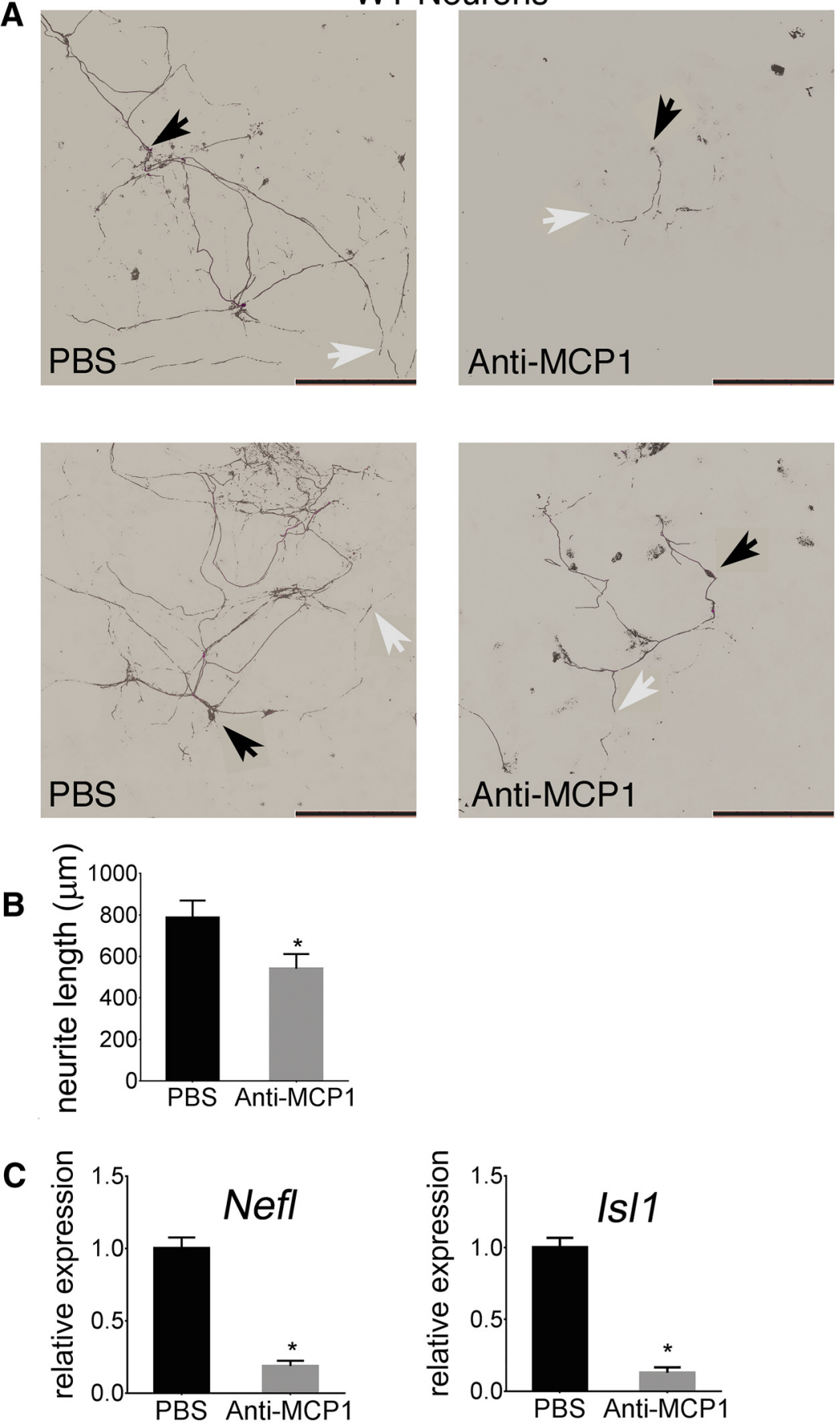

\section{D}
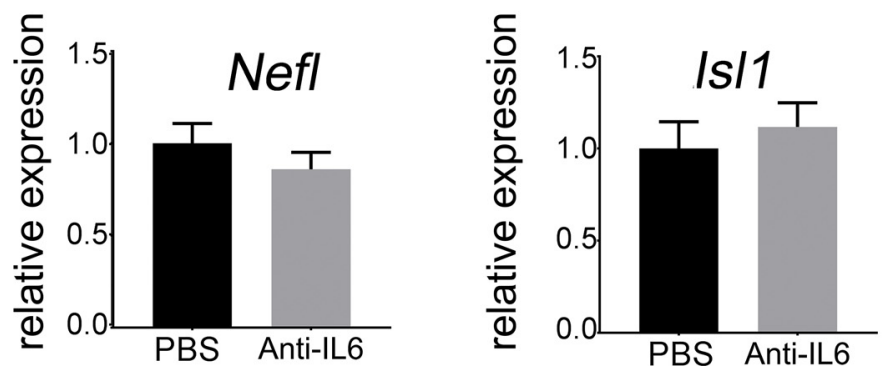

Figure 7. Neutralizing antibody to MCP1 reduced the neurite lengths of cultured WT mouse spinal cord motor neurons. Motor neurons were derived from WT mouse E13.5 spinal cords. The neurons were treated $24 \mathrm{~h}$ after plating for $7 \mathrm{~d}$ with a neutralizing antibody to MCP1 in WT ACM. $\boldsymbol{A}$, Primary neurites as indicated by Nefl immunostaining. $\boldsymbol{B}$, A minimum of 20 neurons were measured and quantified $(p=0.03$ ). Cell soma are indicated by a black arrow and the end of a measured neurite by a white arrow.
Neutralizing antibody to MCP1 blocks supportive effects of WT ACM

When ACM from WT astrocytes was incubated with a neutralizing antibody to MCP1, the neurites of isolated mouse neurons were shorter than when the cells were treated with ACM without the antibody (Fig. $7 A, B$ ). The levels of Isl1 and Nefl mRNA were reduced when the WT ACM was pretreated with the antibody (Fig. 7C). Similar effects were not seen with the addition of antibody to IL-6 (Fig. 7D).

Neutralization of MCP1 also decreased the length of control human iPS-cell-derived motor neuron neurites when added to WT ACM (Fig. 8A) and the corresponding mRNA levels of Nefl were decreased (Fig. 8B). Motor neurons derived from SMA patient iPSCs were also sensitive to MCP1 depletion. The addition of antibody to MCP1 prevented the increase in neurite length of SMA cells in WT ACM (Fig. $8 C$ ) and prevented the increased expression of the motor neuron marker TUBB3 (Fig. 8D). Isl1 mRNA levels were unchanged with treatment of both WT and SMA iPSCs.

\section{Discussion}

Levels of MCP1 in the spinal cord, where it is predominantly produced by astrocytes, are depressed in young SMA mice and the levels in the medium of cultured astrocytes from these mice are reduced. Our data show that increasing MCP1 levels by including WT astrocytes or adding purified recombinant MCP1 increases neurite length and increases expression of motor neuron markers. Restoration of MCP1 to WT levels might improve the axonal integrity and survival of motor neurons from mice and differentiated human iPSCs from both healthy WT controls and SMA patients. The relative mRNA levels of common motor neuron markers were used as a substitute for motor neuron health and overall survival (Ferraiuolo et al., 2007; Ho et al., 2016). Although neurite length in cell culture is an imperfect indicator of neuronal health in vivo, increases in neurite persistence have been associated with resistance to

C, Relative mRNA levels of Nefl $(p=0.0001)$ and $|s| 1$ ( $p=$ 0.0001 ) are reduced in neurons grown in the presence of WT ACM with the neutralizing MCP1 antibody. D, Relative mRNA levels of Nefl and Is 1 were not different between neurons grown in the presence or absence of a neutralizing antibody to IL-6. Neurite data are shown as mean \pm SEM. Relative mRNA levels are normalized to Pgk1. mRNA data are shown as mean $\pm S D$ 
neurotoxicity (Ryan et al., 2016) and used as a marker for neuronal health (Custer et al., 2013; Chen et al., 2016) and regeneration potential (Berretta et al., 2016; Chen et al., 2016; Sun et al., 2016). Restoring MCP1 levels early in SMA might therefore improve disease outcome.

Chemokine signals influence cellular growth and neurite extension. MCP1, in particular, has been linked to neuronal survival during development (Bianchi et al., 2005) and with HIV-induced neurotoxicity in culture (Eugenin et al., 2003). In culture, neurite outgrowth is known to be mediated in part by MCP1 expression (Kwon et al., 2015; Niemi et al., 2016) and the addition of MCP1 increases electrophysiological activity in cultured neurons (Zhou et al., 2016).

Neurons express the MCP1 receptor CCR2 during basal conditions (Coughlan et al., 2000), as do astrocytes during development (Rezaie et al., 2002) and adulthood (Andjelkovic et al., 1999).

MCP1 is a proinflammatory chemokine and has been linked to increases in macrophage infiltration of the CNS. In neurodegeneration, there is evidence that gliosis and overall reactivity increase as disease progresses (Sheng et al., 1997). There is evidence that MCP1 levels rise later in disease in the SMA model mice (Rindt et al., 2015) and of gliosis in patient autopsy tissue (Araki et al., 2003). Therefore, increasing MCP1 might have a narrow range of therapeutic efficacy. Elevation of MCP1 could exacerbate the inflammatory cascade and, if so, increases to MCP1 may have to be avoided after gliosis has begun.

That there is a role of non-neuronal cells in SMA has now been well established (Hua et al., 2011; Paez-Colasante et al., 2013; Hua et al., 2015). Therefore, it is important to discover through what mechanisms astrocytes are involved in SMA. Factors secreted by astrocytes have been linked to neuronal health (Aït-Ikhlef et al., 2000; Nakano et al., 2016) and maturation (Ullian et al., 2004). Supplementation with BDNF, a neurotrophic factor released by astrocytes, has been shown to improve motor neuron health in cell culture and in vivo (Connor et al., 2016; Sun et al., 2016). The expression levels of ISL1, NEFL, and TUBB3 were used in this study to evaluate the overall health status of the motor neurons in culture. It is expected that a reduction in neurite length in our cultured motor neurons would also lead to widespread changes in gene expression. Several studies evaluating transcription in SOD1 models and patient samples with ALS have reported changes in gene expression (Ferraiuolo et al., 2007; Ho et al., 2016) with differences that can depend on the stage of disease. We chose to evaluate ISL1, NEFL, and TUBB3 in this
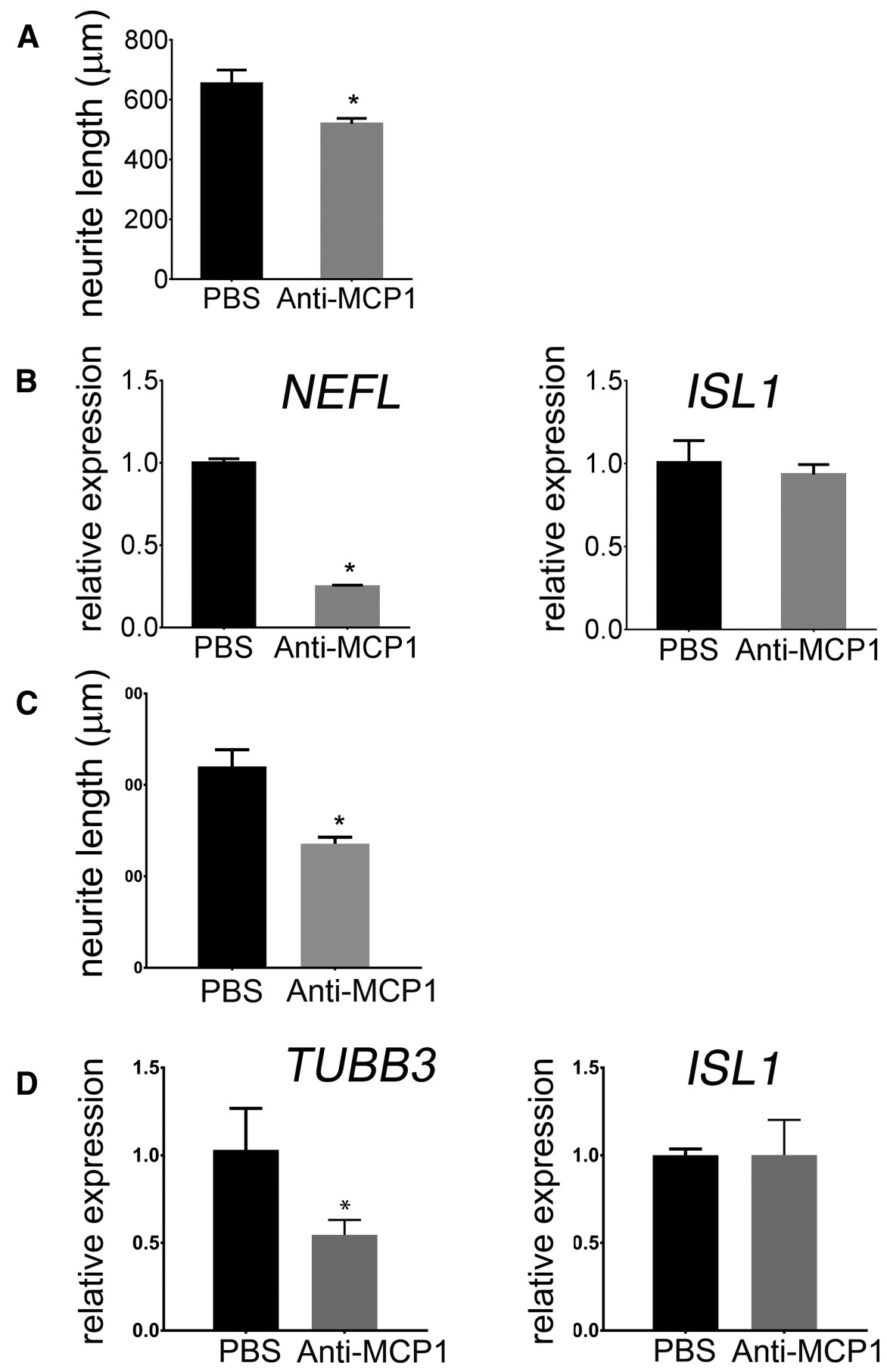

Figure 8. Neutralizing antibody to MCP1 decreases the neurite length of differentiated motor-neuron-like cells from healthy control and SMA iPSCS. After plating for $7 \mathrm{~d}$, the cells were treated for $24 \mathrm{~h}$ with a neutralizing antibody to MCP1 in WT ACM. A, A minimum of 20 neurons were measured and quantified ( $p=0.02)$. $\boldsymbol{B}$, Nefl relative mRNA level is decreased in the presence of the antibody to MCP1 ( $p=0.0001$ ). Neutralizing antibody to MCP1 also decreases the neurite length of differentiated motor-neuronlike cells from SMA patient iPSCs. C, A minimum of 20 neurons were measured and quantified $(p=0.03)$. $D$, The TUBB3 relative mRNA level is decreased in the presence of the antibody to MCP1 $(p=0.017)$. Neurite data are shown as mean \pm SEM. Relative mRNA levels are normalized to Pgk1 and GusB. Relative mRNA data are shown as mean \pm SD.

study to test for toxicity that may affect the levels of these neuronal genes. The overall pattern of gene expression was variable within our study and this may relate to differences in the amount and duration of the toxicity between the motor neuron cells in our tissue culture experiments. The studies by Ferraiuolo et al. (2007) and Ho et al. (2016) have also shown gene expression changes that vary depending on the disease or toxicity duration. 
Overall, our findings implicate the astrocyte-dependent chemokine balance and particularly MCP1 in SMA pathogenesis and indicate that restoration of deficient astrocyte-secreted factors may be worth pursuing as a therapeutic approach. Whereas SMA is caused by the lack of functional SMN protein, the longterm effects may alter cellular processes that are not directly related to SMN protein levels. MCP1 elevation could thus complement other SMN-targeted treatments.

\section{References}

Andjelkovic AV, Kerkovich D, Shanley J, Pulliam L, Pachter JS (1999) Expression of binding sites for beta chemokines on human astrocytes. Glia 28:225-235. Medline

Araki S, Hayashi M, Tamagawa K, Saito M, Kato S, Komori T, Sakakihara Y, Mizutani T, Oda M (2003) Neuropathological analysis in spinal muscular atrophy type II. Acta Neuropathol 106:441-448. CrossRef Medline

Aït-Ikhlef A, Hantaz-Ambroise D, Henderson CE, Rieger F (2000) Influence of factors secrAieted by wobbler astrocytes on neuronal and motoneuronal survival. J Neurosci Res 59:100-106. Medline

Berretta A, Gowing EK, Jasoni CL, Clarkson AN (2016) Sonic hedgehog stimulates neurite outgrowth in a mechanical stretch model of reactiveastrogliosis. Sci Rep 6:21896. CrossRef Medline

Bianchi LM, Daruwalla Z, Roth TM, Attia NP, Lukacs NW, Richards AL, White IO, Allen SJ, Barald KF (2005) Immortalized mouse inner ear cell lines demonstrate a role for chemokines in promoting the growth of developing statoacoustic ganglion neurons. J Assoc Res Otolaryngol 6:355-367. Medline

Bruno V, Copani A, Besong G, Scoto G, Nicoletti F (2000) Neuroprotective activity of chemokines against N-methyl-D-aspartate or beta-amyloidinduced toxicity in culture. Eur J Pharmacol 399:117-121. CrossRef Medline

Burghes AH, Beattie CE (2009) Spinal muscular atrophy: why do low levels of survival motor neuron protein make motor neurons sick? Nat Rev Neurosci 10:597-609. CrossRef Medline

Chen K, Lu H, Gao T, Xue X, Wang C, Miao F (2016) Synergic interaction between amyloid precursor protein and neural cell adhesion molecule promotes neurite outgrowth. Oncotarget 7:14199-14206. CrossRef Medline

Clement AM, Nguyen MD, Roberts EA, Garcia ML, Boillée S, Rule M, McMahon AP, Doucette W, Siwek D, Ferrante RJ, Brown RH Jr, Julien JP, Goldstein LS, Cleveland DW (2003) WT nonneuronal cells extend survival of SOD1 mutant motor neurons in ALS mice. Science 302:113-117. CrossRef Medline

Connor B, Sun Y, von Hieber D, Tang SK, Jones KS, Maucksch C (2016) AAV1/2-mediated BDNF gene therapy in a transgenic rat model of Huntington's disease. Gene Ther 23:283-295. CrossRef Medline

Coovert DD, Le TT, McAndrew PE, Strasswimmer J, Crawford TO, Mendell JR, Coulson SE, Androphy EJ, Prior TW, Burghes AH (1997) The survival motor neuron protein in spinal muscular atrophy. Hum Mol Genet 6:1205-1214. CrossRef Medline

Coughlan CM, McManus CM, Sharron M, Gao Z, Murphy D, Jaffer S, Choe W, Chen W, Hesselgesser J, Gaylord H, Kalyuzhny A, Lee VM, Wolf B, Doms RW, Kolson DL (2000) Expression of multiple functional chemokine receptors and monocyte chemoattractant protein-1 in human neurons. Neuroscience 97:591-600. CrossRef Medline

Custer SK, Todd AG, Singh NN, Androphy EJ (2013) Dilysine motifs in exon $2 \mathrm{~b}$ of SMN protein mediate binding to the COPI vesicle protein alpha-COP and neurite outgrowth in a cell culture model of spinal muscular atrophy. Hum Mol Genet 22:4043-4052. CrossRef Medline

Elsheikh B, Prior T, Zhang X, Miller R, Kolb SJ, Moore D, Bradley W, Barohn R, Bryan W, Gelinas D, Iannaccone S, Leshner R, Mendell JR, Mendoza M, Russman B, Smith S, King W, Kissel JT (2009) An analysis of disease severity based on SMN2 copy number in adults with spinal muscular atrophy. Muscle Nerve 40:652-656. CrossRef Medline

Eugenin EA, D’Aversa TG, Lopez L, Calderon TM, Berman JW (2003) MCP-1 (CCL2) protects human neurons and astrocytes from NMDA or HIV-tatinduced apoptosis. J Neurochem 85:1299-1311. CrossRef Medline

Ferraiuolo L, Heath PR, Holden H, Kasher P, Kirby J, Shaw PJ (2007) Microarray analysis of the cellular pathways involved in the adaptation to and progression of motor neuron injury in the SOD1 G93A mouse model of familial ALS. J Neurosci 27:9201-9219. CrossRef Medline

Foran E, Rosenblum L, Bogush A, Pasinelli P, Trotti D (2014) Sumoylation of the astroglial glutamate transporter EAAT2 governs its intracellular compartmentalization. Glia 62:1241-1253. CrossRef Medline

Foust KD, Wang X, McGovern VL, Braun L, Bevan AK, Haidet AM, Le TT, Morales PR, Rich MM, Burghes AH, Kaspar BK (2010) Rescue of the spinal muscular atrophy phenotype in a mouse model by early postnatal delivery of SMN. Nat Biotechnol 28:271-274. CrossRef Medline

Frühbeis C, Fröhlich D, Kuo WP, Krämer-Albers EM (2013) Extracellular vesicles as mediators of neuron-glia communication. Front Cell Neurosci 7:182. Medline

Genis L, Dávila D, Fernandez S, Pozo-Rodrigálvarez A, Martínez-Murillo R, Torres-Aleman I (2014) Astrocytes require insulin-like growth factor I to protect neurons against oxidative injury. F1000Res 3:28. CrossRef Medline

Gibb SL, Boston-Howes W, Lavina ZS, Gustincich S, Brown RH Jr, Pasinelli $\mathrm{P},{ }^{* *}$ Trotti D (2007) A caspase-3-cleaved fragment of the glial glutamate transporter EAAT2 is sumoylated and targeted to promyelocytic leukemia nuclear bodies in mutant SOD1-amyotrophic lateral sclerosis. J Biol Chem 282:32480-32490. CrossRef Medline

Gogliotti RG, Quinlan KA, Barlow CB, Heier CR, Heckman CJ, Didonato CJ (2012) Motor neuron rescue in spinal muscular atrophy mice demonstrates that sensory-motor defects are a consequence, not a cause, of motor neuron dysfunction. J Neurosci 32:3818-3829. CrossRef Medline

Grunseich C, Zukosky K, Kats IR, Ghosh L, Harmison GG, Bott LC, Rinaldi C, Chen KL, Chen G, Boehm M, Fischbeck KH (2014) Stem cell-derived motor neurons from spinal and bulbar muscular atrophy patients. Neurobiol Dis 70:12-20. CrossRef Medline

Hansson E, Muyderman H, Leonova J, Allansson L, Sinclair J, Blomstrand F, Thorlin T, Nilsson M, Rönnbäck L (2000) Astroglia and glutamate in physiology and pathology: aspects on glutamate transport, glutamateinduced cell swelling and gap-junction communication. Neurochem Int 37:317-329. CrossRef Medline

Ho R, Sances S, Gowing G, Amoroso MW, O’Rourke JG, Sahabian A, Wichterle H, Baloh RH, Sareen D, Svendsen CN (2016) ALS disrupts spinal motor neuron maturation and aging pathways within gene co-expression networks. Nat Neurosci 19:1256-1267. CrossRef Medline

Hua Y, Sahashi K, Rigo F, Hung G, Horev G, Bennett CF, Krainer AR (2011) Peripheral SMN restoration is essential for long-term rescue of a severe spinal muscular atrophy mouse model. Nature 478:123-126. CrossRef Medline

Hua Y, Liu YH, Sahashi K, Rigo F, Bennett CF, Krainer AR (2015) Motor neuron cell-nonautonomous rescue of spinal muscular atrophy phenotypes in mild and severe transgenic mouse models. Genes Dev 29:288297. CrossRef Medline

Jeong HK, Ji KM, Min KJ, Choi I, Choi DJ, Jou I, Joe EH (2014) Astrogliosis is a possible player in preventing delayed neuronal death. Mol Cells 37: 345-355. CrossRef Medline

Jiang R, Diaz-Castro B, Looger LL, Khakh BS (2016) Dysfunctional calcium and glutamate signaling in striatal astrocytes from Huntington's disease model mice. J Neurosci 36:3453-3470. CrossRef Medline

Kondo T, Funayama M, Tsukita K, Hotta A, Yasuda A, Nori S, Kaneko S, Nakamura M, Takahashi R, Okano H, Yamanaka S, Inoue H (2014) Focal transplantation of human iPSC-derived glial-rich neural progenitors improves lifespan of ALS mice. Stem Cell Reports 3:242-249. CrossRef Medline

Kwon MJ, Shin HY, Cui Y, Kim H, Thi AH, Choi JY, Kim EY, Hwang DH, Kim BG (2015) CCL2 mediates neuron-macrophage interactions to drive proregenerative macrophage activation following preconditioning injury. J Neurosci 35:15934-15947. CrossRef Medline

Lee AJ, Awano T, Park GH, Monani UR (2012) Limited phenotypic effects of selectively augmenting the SMN protein in the neurons of a mouse model of severe spinal muscular atrophy. PLoS One 7:e46353. CrossRef Medline

Lefebvre S, Burlet P, Liu Q, Bertrandy S, Clermont O, Munnich A, Dreyfuss G, Melki J (1997) Correlation between severity and SMN protein level in spinal muscular atrophy. Nat Genet 16:265-269. CrossRef Medline

Madrigal JL, Leza JC, Polak P, Kalinin S, Feinstein DL (2009) Astrocytederived MCP-1 mediates neuroprotective effects of noradrenaline. J Neurosci 29:263-267. CrossRef Medline

Martinez TL, Kong L, Wang X, Osborne MA, Crowder ME, Van Meerbeke JP, Xu X, Davis C, Wooley J, Goldhamer DJ, Lutz CM, Rich MM, Sumner CJ (2012) Survival motor neuron protein in motor neurons determines syn- 
aptic integrity in spinal muscular atrophy. J Neurosci 32:8703-8715. CrossRef Medline

McGivern JV, Patitucci TN, Nord JA, Barabas ME, Stucky CL, Ebert AD (2013) Spinal muscular atrophy astrocytes exhibit abnormal calcium regulation and reduced growth factor production. Glia 61:1418-1428. CrossRef Medline

Miao SH, Sun HB, Ye Y, Yang JJ, Shi YW, Lu M, Hu G, Zhou JW (2014) Astrocytic JWA expression is essential to dopaminergic neuron survival in the pathogenesis of Parkinson's disease. CNS Neurosci Ther 20:754-762 CrossRef Medline

Monani UR (2005) Spinal muscular atrophy: a deficiency in a ubiquitous protein; a motor-neuron-specific disease. Neuron 48:885-896. CrossRef Medline

Monani UR, Lorson CL, Parsons DW, Prior TW, Androphy EJ, Burghes AH, McPherson JD (1999) A single nucleotide difference that alters splicing patterns distinguishes the SMA gene SMN1 from the copy gene SMN2. Hum Mol Genet 8:1177-1183. CrossRef Medline

Nakano N, Kanekiyo K, Nakagawa T, Asahi M, Ide C (2016) NTAK/ Neuregulin-2 secreted by astrocytes promotes survival and neurite outgrowth of neurons via ErbB3. Neurosci Lett 622:88-94 CrossRef Medline

Niemi JP, DeFrancesco-Lisowitz A, Cregg JM, Howarth M, Zigmond RE (2016) Overexpression of the monocyte chemokine CCL2 in dorsal root ganglion neurons causes a conditioning-like increase in neurite outgrowth and does so via a STAT3 dependent mechanism. Exp Neurol 275:25-37. CrossRef Medline

Paez-Colasante X, Seaberg B, Martinez TL, Kong L, Sumner CJ, Rimer M (2013) Improvement of neuromuscular synaptic phenotypes without enhanced survival and motor function in severe spinal muscular atrophy mice selectively rescued in motor neurons. PLoS One 8:e75866. CrossRef Medline

Park GH, Maeno-Hikichi Y, Awano T, Landmesser LT, Monani UR (2010) Reduced survival of motor neuron (SMN) protein in motor neuronal progenitors functions cell autonomously to cause spinal muscular atrophy in model mice expressing the human centromeric (SMN2) gene. J Neurosci 30:12005-12019. CrossRef Medline

Patitucci TN, Ebert AD (2016) SMN deficiency does not induce oxidative stress in SMA iPSC-derived astrocytes or motor neurons. Hum Mol Genet. 25:514-523. CrossRef Medline

Pavelko KD, Howe CL, Drescher KM, Gamez JD, Johnson AJ, Wei T, Ransohoff RM, Rodriguez M (2003) Interleukin-6 protects anterior horn neurons from lethal virus-induced injury. J Neurosci 23:481-492. Medline

Pearn JH (1973) The gene frequency of acute Werdnig-Hoffmann disease (SMA type 1). A total population survey in North-East England. J Med Genet 10:260-265. CrossRef Medline

Pehar M, Cassina P, Vargas MR, Castellanos R, Viera L, Beckman JS, Estévez AG, Barbeito L (2004) Astrocytic production of nerve growth factor in motor neuron apoptosis: implications for amyotrophic lateral sclerosis. J Neurochem 89:464-473. CrossRef Medline

Rangroo Thrane V, Thrane AS, Wang F, Cotrina ML, Smith NA, Chen M, Xu Q, Kang N, Fujita T, Nagelhus EA, Nedergaard M (2013) Ammonia triggers neuronal disinhibition and seizures by impairing astrocyte potassium buffering. Nat Med 19:1643-1648. CrossRef Medline

Rezaie P, Trillo-Pazos G, Everall IP, Male DK (2002) Expression of betachemokines and chemokine receptors in human fetal astrocyte and microglial co-cultures: potential role of chemokines in the developing CNS. Glia 37:64-75. CrossRef Medline

Rindt H, Feng Z, Mazzasette C, Glascock JJ, Valdivia D, Pyles N, Crawford TO, Swoboda KJ, Patitucci TN, Ebert AD, Sumner CJ, Ko CP, Lorson CL
(2015) Astrocytes influence the severity of spinal muscular atrophy. Hum Mol Genet 24:4094-4102. CrossRef Medline

Robbins KL, Glascock JJ, Osman EY, Miller MR, Lorson CL (2014) Defining the therapeutic window in a severe animal model of spinal muscular atrophy. Hum Mol Genet 23:4559-4568. CrossRef Medline

Rosito M, Deflorio C, Limatola C, Trettel F (2012) CXCL16 orchestrates adenosine $\mathrm{A} 3$ receptor and $\mathrm{MCP}-1 / \mathrm{CCL} 2$ activity to protect neurons from excitotoxic cell death in the CNS. J Neurosci 32:3154-3163. CrossRef Medline

Rothstein JD, Dykes-Hoberg M, Pardo CA, Bristol LA, Jin L, Kuncl RW, Kanai Y, Hediger MA, Wang Y, Schielke JP, Welty DF (1996) Knockout of glutamate transporters reveals a major role for astroglial transport in excitotoxicity and clearance of glutamate. Neuron 16:675-686. CrossRef Medline

Ryan KR, Sirenko O, Parham F, Hsieh JH, Cromwell EF, Tice RR, Behl M (2016) Neurite outgrowth in human induced pluripotent stem cell-derived neurons as a high-throughput screen for developmental neurotoxicity or neurotoxicity. Neurotoxicology 53:271-281. CrossRef Medline

Sheng JG, Mrak RE, Griffin WS (1997) Glial-neuronal interactions in Alzheimer disease: progressive association of IL-1alpha+ microglia and S100beta + astrocytes with neurofibrillary tangle stages. J Neuropathol Exp Neurol 56:285-290. CrossRef Medline

Stowe AM, Wacker BK, Cravens PD, Perfater JL, Li MK, Hu R, Freie AB, Stüve O, Gidday JM (2012) CCL2 upregulation triggers hypoxic preconditioninginduced protection from stroke. J Neuroinflammation 9:33. CrossRef Medline

Sugarman EA, Nagan N, Zhu H, Akmaev VR, Zhou Z, Rohlfs EM, Flynn K, Hendrickson BC, Scholl T, Sirko-Osadsa DA, Allitto BA (2012) Panethnic carrier screening and prenatal diagnosis for spinal muscular atrophy: clinical laboratory analysis of $>72,400$ specimens. Eur J Hum Genet 20:27-32. CrossRef Medline

Sun F, Nguyen T, Jin X, Huang R, Chen Z, Cunningham RL, Singh M, Su C (2016) Pgrmc1/BDNF signaling plays a critical role in mediating glianeuron crosstalk. Endocrinology 157:2067-2079. CrossRef Medline

Sun Z, Dai X, Li Y, Jiang S, Lou G, Cao Q, Hu R, Huang Y, Su Z, Chen M, Luo H, Lin X, Sun J, Xiao F (2016) A novel Nogo-66 receptor antagonist peptide promotes neurite regeneration in vitro. Mol Cell Neurosci 71:80 91. CrossRef Medline

Suzuki A, Stern SA, Bozdagi O, Huntley GW, Walker RH, Magistretti PJ, Alberini CM (2011) Astrocyte-neuron lactate transport is required for long-term memory formation. Cell 144:810-823. CrossRef Medline

Taylor AR, Robinson MB, Milligan CE (2007) In vitro methods to prepare astrocyte and motoneuron cultures for the investigation of potential in vivo interactions. Nat Protoc 2:1499-1507. CrossRef Medline

Tong X, Ao Y, Faas GC, Nwaobi SE, Xu J, Haustein MD, Anderson MA, Mody I, Olsen ML, Sofroniew MV, Khakh BS (2014) Astrocyte Kir4.1 ion channel deficits contribute to neuronal dysfunction in Huntington's disease model mice. Nat Neurosci 17:694-703. CrossRef Medline

Ullian EM, Harris BT, Wu A, Chan JR, Barres BA (2004) Schwann cells and astrocytes induce synapse formation by spinal motor neurons in culture. Mol Cell Neurosci 25:241-251. CrossRef Medline

Wisman LA, van Muiswinkel FL, de Graan PN, Hol EM, Bär PR (2003) Cells over-expressing EAAT2 protect motoneurons from excitotoxic death in vitro. Neuroreport 14:1967-1970. CrossRef Medline

Zhou C, Feng Z, Ko CP (2016) Defects in motoneuron-astrocyte interactions in spinal muscular atrophy. J Neurosci 36:2543-2553. CrossRef Medline 